\title{
Poetyka \\ w świetle kulturoznawstwa
}

\section{Tomasz Kunz}

Z osobliwym uczuciem czyta się dzisiaj pisany w połowie lat 80. ubiegłego wieku tekst Michała Głowińskiego, w którym ten wybitny badacz i teoretyk literatury zapowiada ostateczne przezwyciężenie odziedziczonego po przełomie antypozytywistycznym dychotomicznego podziału na metody zewnętrzne i wewnętrzne oraz nastanie nowej ery w badaniach literackich dzięki zastosowaniu metody integralnej, której podstawę miała stanowić komunikacjonistyczna koncepcja dzieła literackiego ${ }^{1}$. Rzeczywistość nader surowo obeszła się z uzasadnionymi wszak nadziejami na spektakularne zwieńczenie najlepszego i bez wątpienia najoryginalniejszego okresu w historii polskiej myśli teoretycznoliterackiej. Zmiana paradygmatu istotnie nastąpiła, ale przybrała formę całkowicie odmienną od tej, jakiej spodziewali się nasi komunikacjoniści.

Poststrukturalistyczno-dekonstrukcjonistyczna rewolta, która nastąpiła w polskim literaturoznawstwie w latach 90. ubiegłego wieku, doprowadziła do konceptualnego demontażu nowoczesnej teorii literatury i faktycznego zerwania ewolucyjnej ciągłości polskiej refleksji teoretycznoliterackiej, przygotowując grunt pod późniejszy zwrot, jaki dokonał faktycznego, głębokiego przekształcenia zarówno przedmiotu studiów literaturoznawczych, jak i samego dyskursu literaturoznawczego. Rewolta ta, widziana z dzisiejszej perspektywy, przypomina pod wieloma względami przesunięty w czasie epistemologiczny spektakl odegrany według scenariusza, który pomijał społeczną, polityczną i historyczną specyfikę polskiej tradycji humanistycznej, a także szczególną kulturotwórczą i tożsamościową funkcję literatury oraz samych studiów polonistycznych zarówno w ich historyczno-, jak i teoretycznoliterackim aspekcie ${ }^{2}$. Proces, który w zachodnim literaturoznawstwie dokonywał się poprzez systematyczną i roz-

\footnotetext{
${ }^{1}$ M. Głowiński, Od metod zewnętrznych i wewnętrznych do komunikacji literackiej, [w:] tegoż, Dzieło wobec odbiorcy. Szkice z komunikacji literackiej, t. 3: Prace wybrane Michała Głowińskiego, red. R. Nycz, Kraków 1998, s. 7-23.

2 Jest do napisania (kulturowa) historia polskiej myśli teoretycznoliterackiej, która uwzględniałaby nie tylko złożone intelektualne skutki pospiesznego przyswajania zachodnich teorii, ale także wpływ specyficznych, lokalnych czynników historycznych, politycznych i społecznych na formę i skutki recepcji idei i koncepcji wypracowanych w odmiennych warunkach kulturowych. Zob. ciekawe ujęcie tej problematyki w szerszym, polityczno-kulturowym kontekście w artykule Galina Tihanova Dlaczego nowoczesna teoria literatury narodziła się w Europie Środkowej i Wschodniej? (I dlaczego dziś jest martwa?), „Teksty Drugie” 2007, nr 4, s. 131-152.
} 
łożoną na niemal ćwierćwiecze intensywną, krytyczną refleksję, u nas sprowadził się przede wszystkim do wzmożonej aktywności translatorskiej i edytorskiej, skoncentrowanej na prezentacji i popularyzacji teoretycznych założeń, nie znajdującej jednak z reguły przełożenia na działalność interpretacyjną, rzadko też prowadzącej do prób oryginalnego, krytycznego rozwijania referowanych koncepcji. Aplikowalność dekonstrukcjonistycznych narzędzi do badań nad literaturą polską okazała się na tyle niewielka, że Janusz Sławiński w połowie lat 90. mógł z satysfakcją i ironią konstatować faktyczny rozdźwięk między apokaliptycznymi proklamacjami a codzienną praktyką literaturoznawczą, choć wyliczane przez niego przykłady owej praktyki brzmiały już wówczas niepokojąco anachronicznie ${ }^{3}$ i pozwalały domniemywać, że wyłaniający się z nich, afirmatywny w założeniu autora, obraz sumiennej skrzętności akademickich polonistów wynika raczej z rutyny i konserwatywnej niechęci wobec jakichkolwiek zmian niż z racjonalnej chęci obrony statusu własnej dyscypliny.

Nim jeszcze na dobre zakończył się proces przyspieszonego przyswajania lekcji poststrukturalizmu i dekonstrukcji, rozpoczęła się równie błyskawiczna asymilacja nurtów teoretycznych kojarzonych ze zwrotem kulturowym. Te dwa wielkie przewroty metodologiczne, które na Zachodzie rozłożyły się na kilka dekad, u nas dokonały się niejako równolegle, co utrudniło właściwe zrozumienie swoistych i odrębnych konsekwencji, jakie każdy z nich przyniósł studiom literackim. Mówiąc w największym skrócie, zmiana, jaka dotknęła literaturoznawstwo w okresie ekspansji poststrukturalizmu i dekonstrukcji, polegała przede wszystkim na odejściu od autonomicznie i homogenicznie rozumianej teorii literatury, skoncentrowanej na poszukiwaniu ogólnych zasad budowy i wytwarzania dzieła literackiego oraz specyfiki jego językowej konstrukcji, a więc tego wszystkiego, co określane bywało mianem instytucjonalnie pojmowanej literackości. Zainteresowanie badaczy skierowało się w stronętekstu literackiego, który pozbawiono jednak przedmiotowego statusu, usiłując - przynajmniej na poziomie deklaracji - przywrócić mu utracony jednostkowy wymiar poprzez podważanie teoretycznych obramowań i metafizycznych założeń rządzących interpretacją oraz relacją badacza i tekstu. Obiektem ataku stała się zatem nowoczesna teoria literatury w jej najbardziej ortodoksyjnym, scjentystycznym wydaniu, odwołująca się do sformalizowanego i stechnicyzowanego modelu poetyki lingwistycznej - poetyki w świetle językoznawstwa - zorientowana w głównej mierze, jeśli nie wyłącznie na opis i analizę systemowego wymiaru literatury. Teoria zachowująca wyniosłą obojętność zarówno wobec jednostkowości czy też zdarzeniowości tekstu literackiego, jak i wobec indywidualnego aktu jego interpretacji lub też narzucająca tej ostatniej poznawcze ograniczenia i zuniformizowane procedury.

W praktyce jednak dekonstrukcja, podważywszy wszystkie bez mała aksjomaty nowoczesnej teorii literatury, nie naruszyła właściwego strukturalizmowi paradygmatu tekstualistycznego, podtrzymując zainteresowanie językowymi mechanizmami tworzenia znaczeń. Przenio-

\footnotetext{
${ }^{3}$ Większość literaturoznawców, pisał Sławiński, „przechodzi bez dalszych hamletyzowań do normalnych prac zawodowych, które podtrzymują i potwierdzają jej egzystencję: trzeba wszak napisać zamówiony artykuł o konieczności piątej warstwy w Ingardenowskim modelu dzieła literackiego, wyjaśnić studentom, kto naprawdę jest adresatką Rozłączenia Słowackiego, zaopiniować rozprawę doktorską o narracji personalnej w powieściach Żeromskiego, zarekomendować do druku książkę młodego autora o autobiograficznych sekretach pisarstwa Berenta... Gdy patrzeć na teraźniejszą wiedzę o literaturze od strony jej powszechnych zadań, rutyny podejmowanych zobowiązań i robót, może się ona wydawać instytucją osobliwie stabilną - uodpornioną na zagrażające jej zewsząd przełomy, przewroty, akty likwidacyjne czy nihilistyczne zamachy". J. Sławiński, Miejsce interpretacji, [w:] tegoż, Miejsce interpretacji, Gdańsk 2006, s. 85-86.
} 
sła jedynie akcent na te właściwości tekstu, które uniemożliwiają nadanie mu ostatecznego, całościowego sensu i nie pozwalają wywikłać się z wewnętrznych sprzeczności i aporii towarzyszących jego wykładni. Wszystko to pozwalało żywić nadzieję, że po wyhamowaniu impetu krytycznego i antyteoretycznego, reprezentowanego głównie przez szkołę dekonstrukcji z Yale, literaturoznawstwo zachowa swoją dyscyplinarną odrębność opartą na specyfice własnego przedmiotu i metodologii ${ }^{4}$.

Poststrukturalizm i dekonstrukcja podważyły podstawowe przekonania, którym hołdowała nowoczesna teoria literatury, nie zaproponowały jednak w istocie alternatywnego projektu uprawiania studiów literackich, przekładających się bezpośrednio na lekturową praktykę. Brak nowych, oryginalnych odczytań i interpretacji inspirowanych teoretycznymi założeniami dekonstrukcji pozwalał przyjmować z dystansem proklamacje o „kryzysie dyscypliny” i przeciwstawiać im praktykę interpretacyjno-krytyczną odwołującą się w dalszym ciągu do tradycyjnych kategorii literaturoznawczych i tradycyjnego pojmowania przez badaczy i krytyków ich profesjonalnych powinności. Faktycznej zmiany dokonał dopiero zwrot antropologiczno-kulturowy, odbierający pojęciu tekstu/tekstowości jego wcześniejsze znaczenie i wprowadzając nowe, kulturowe rozumienie przedmiotu studiów literackich. Wypada zatem zgodzić się z Galinem Tihanovem, który kres „teorii literatury jako odrębnej dyscypliny naukowej” wiąże nie $z$ poststrukturalizmem i dekonstrukcją, ale dopiero $\mathrm{z}$ dokonanym przez Wolfganga Isera zwrotem ku „antropologii literackiej”" Miejsce teorii literatury zajęła wówczas ogólna teoria kultury, a tekstowy świat literatury zanurzył się w kulturowym uniwersum, w którym prototypowy charakter utworów literackich pozostaje, jak się wydaje, jedynie pobożnym życzeniem literaturoznawców, próbujących przebić się ze swoimi narzędziami do pierwszego szeregu badaczy tworzących awangardę współczesnych studiów kulturowych. Literaturę można oczywiście uznawać za przedmiot prototypowy, ale trzeba też brać pod uwagę, że równie dobrze może się ona okazać „drobną, niczym nie wyróżnioną cząstką wszystkich tekstów funkcjonujących w kulturze i przez tę kulturę deformowanych"6.

Jak prezentuje się w tym kontekście dzisiejszy status teorii literatury i poetyki w kulturowo zorientowanym literaturoznawstwie? By móc udzielić choćby prowizorycznej odpowiedzi na tak postawione pytanie, należy przede wszystkim pamiętać, że status owych dyscyplin uzależniony jest ściśle od statusu samego przedmiotu studiów literackich. Nie jest już nim z pewnością tradycyjnie rozumiana literatura, pojęta jako swoista dziedzina przedmiotowa, wyodrębniona na podstawie szczególnych właściwości, które przypisywane są pewnej kategorii tekstów i rozstrzygają o ich literackości. W wyodrębnieniu owego specyficznego przedmiotu oraz w idącym w ślad za tym stworzeniu swoistych metod jego analizy i opisu można widzieć, jak chce tego Michał Paweł Markowski, grzech pierworodny literaturoznawstwa, „absolutyzację

\footnotetext{
${ }^{4}$ Peter Brooks, opisując atmosferę panującą na wydziałach literatury uniwersytetów amerykańskich w połowie lat 80., wspominał między innymi o dość powszechnym oczekiwaniu na bardziej zaawansowane i krytyczne badania tekstualne, korzystające $z$ inspiracji poststrukturalistycznych, skoncentrowane jednak w dalszym ciągu na analizie uogólnionych reguł wytwarzania znaczeń w tekstach literackich. Zob. P. Brooks, Aesthetics and Ideology. What Happened to Poetics?, „Critical Inquiry” 1994, vol. 20, nr 3, s. 509.

${ }^{5}$ G. Tihanov, Dlaczego nowoczesna teoria literatury..., dz. cyt., s. 131.

${ }^{6}$ W. Bolecki, Pytania o przedmiot literaturoznawstwa, [w:]Polonistyka w przebudowie, t. 1, red. zespół M. Czermińskiej (przewodn.), Kraków 2005, s. 7.
} 
jednego języka opisu, fetyszyzację jednego rodzaju dyskursu"7. Nie sposób jednak zaprzeczyć, że właśnie tej pogłębionej refleksji nad naturą, charakterem i podstawami własnej dziedziny przedmiotowej nauka o literaturze zawdzięcza zarówno swoją genezę, jak i najbardziej spektakularne osiągnięcia. Warto także pamiętać, że dążenie to miało charakter procesu ciągłego, którego wymiar historyczny pozwala dziś dostrzec w dziejach nowoczesnej teorii literatury najważniejszy być może impuls krytyczny dla całego XX-wiecznego literaturoznawstwa - także dla historii literatury, z którą teoria pozostawała w permanentnym dialektycznym splocie, problematyzując i kwestionując niestrudzenie założenia i aksjomaty dyscypliny, którą sama ufundowała.

Jeśli teoria literatury pozostaje już dzisiaj jedynie historią XX-wiecznych doktryn literaturoznawczych, to przede wszystkim dlatego, że jej przedmiot, jakim było dzieło literackie czy ogólnie pojęta literackość wyodrębnione na podstawie pewnych - historycznie zmiennych, prowizorycznych i zawsze nieostatecznych, ale przynajmniej lokalnie i tymczasowo wiążących - kryteriów, posiada już wyłącznie status historyczny, należący do bezpowrotnie zamkniętej epoki. Jej początek wyznacza rosyjska szkoła formalna, a koniec, przynajmniej w Polsce, socjologicznie zorientowana teoria komunikacji literackiej, ktora chronologicznie stanowi ostatnią odmianę refleksji strukturalistycznej, zorientowanej na analizę owego swoistego dla niej przedmiotu, cechującego się szczególną formą językowej organizacji. Nie oznacza to jednak, że teoria literatury ma już jedynie znaczenie antykwaryczne. Przeciwnie, jako odrębna dziedzinastudiów polonistycznych jest nieodzowna dla ich dalszego trwania, gdyż tylko ona dostarcza narzędzi pozwalających w skuteczny sposób argumentować na rzecz odrębności i specyfiki literatury jako przedmiotu, który pomimo swojej kulturowej i historycznej natury, może zasadnie aspirować do miana przedmiotu pod pewnymi - zarówno estetycznymi, jak i poznawczymi - względami uprzywilejowanego na tle wszelkich innych wytworów kulturowej działalności człowieka (choćby tylko za sprawą swojej budowy formalnej, wymagającej szczególnego sposobu odbioru $)^{8}$.

Oczywiście teoria literatury poprzez związanie swego przedmiotu z pewnym szczególnym językiem jego przedstawiania w tym samym stopniu dokonuje jego opisu, co stwarza lub wynajduje ów przedmiot. Pedagogiczne pożytki płynące z nauczania dziejów XX-wiecznej teorii literatury nie polegają zatem na obstawaniu przy uniwersalnej - a przez to ahistorycznej - prawdziwości, adekwatności czy wyłączności owego języka, ale na ukazaniu jego historycznej natury, przywracającej samemu przedmiotowi jego - w znacznej mierze zapoznany - historyczny, a jednocześnie konstruktywistyczny wymiar. Jest to tym istotniejsze, że właśnie kulturowo-antropologiczna reorientacja badań literackich przyczyniła się w praktyce, wbrew deklarowanym założeniom, do zawężenia i spłaszczenia perspektywy historycznej analizowanych zjawisk ${ }^{9}$.

${ }^{7}$ M.P. Markowski, Polityka wrażliwości. Wprowadzenie do humanistyki, Kraków 2013, s. 209.

${ }^{8}$ Osobną kwestią jest to, czy zależy nam na zachowaniu owej tożsamości (studiów polonistycznych i ich przedmiotu), co nie jest wcale oczywiste. Być może studia polonistyczne powinny zrezygnować ze statusu filologii narodowej i stać się integralną częścią studiów literackich, te zaś powinny stopniowo przekształcać się w subdyscyplinę studiów kulturowych?

${ }^{9}$ Podobne stanowisko zajmuje w tej kwestii Włodzimierz Bolecki, który zauważa, że konsekwencje zwrotu kulturowego w badaniach literackich „cechuje w zakresie metodologii (...) radykalne zerwanie z historyzmem, a w zakresie przedmiotu literaturoznawstwa z historią literatury. Oba skutkują odrzuceniem historyczności jako integralnej cechy wszelkich zjawisk społecznych i kulturowych oraz jako elementarnego horyzontu poznawczego wszelkich aktów poznawczych w humanistyce". W. Bolecki, Pytania..., dz. cyt., s. 7. 
Jeśli nowoczesna teoria literatury sprawia dzisiaj wrażenie dyscypliny pozbawionej nie tylko przyszłości, ale także praktycznego znaczenia dla kulturowo zorientowanych badań literackich, to poetyka wydaje się zajmować miejsce stosunkowo bezpieczne, o czym świadczą nie tylko popularność tego pojęcia, używanego obecnie w humanistyce w niestandardowych i często dyskusyjnych zestawieniach („poetyka płci”, „poetyka doświadczenia”, „somatopoetyka”, „geopoetyka”), lecz także sprawdzona wielokrotnie praktyczna użyteczność wypracowanych przez nią narzędzi, które służą nie tylko analizie, lecz także interpretacji wszelkiego typu tekstów (przydatność kategorii poetologicznych w różnych dziedzinach humanistyki potwierdza choćby popularność kategorii narracji we współczesnych badaniach historycznych). Tak rozumiana poetyka, zorientowana na pragmatykę interpretacyjno-krytyczną, nie jest już oczywiście „ogólną teorią”, która odkrywa uniwersalne metody tworzenia znaczeń w dziele literackim, lecz raczej zasobnikiem praktycznych narzędzi znajdujących się na usługach rozmaitych praktyk tekstualnych i dyskursywnych. Relacje między teorią literatury, poetyką, teorią interpretacji a samą interpretacją mają charakter złożony i nie dają się, jak sądzę, sprowadzić - jak to onegda jproponował Michał Paweł Markowski - do nieprzezwyciężalnego antagonizmu między afirmatywną i ożywczą interpretacją a wyjałowioną teorią, która ostatecznie przybiera zawsze postać „analitycznej poetyki” lub „filozofującej teorii interpretacji"10.

Sam podział zaproponowany przez Markowskiego wydaje się jednak trafny. Nowoczesna teoria literatury bowiem, mimo mnogości szkół i tradycji badawczych, podzielić można na dwa zasadnicze obozy. Pierwszy z nich, do którego zaliczyć należy wszystkie nurty formalno-strukturalne (od formalistów rosyjskich, przez strukturalizm, po francuską szkołę narratologiczną), ale także Ingardenowską fenomenologiczną teorię budowy dzieła literackiego, zajmował się poszukiwaniem ogólnych, systemowych reguł tworzenia i funkcjonowania wypowiedzi literackiej, „gramatyką literatury”, obejmującą również sformalizowany model poetyki. Drugi skupiał te szkoły teoretyczne, które w centrum swojego zainteresowania stawiały interpretację tekstu literackiego, starając się opracować tak czy inaczej rozumianą „teorię interpretacji”, a więc rodzaj ogólnych wytycznych służących poprawnej interpretacji lub, częściej, pewien model teoretyczny odnoszący się do samego aktu interpretacji. Tutaj zaliczyć trzeba wszystkie nurty hermeneutyczne ( $w$ tym także na przykład lekturę psychoanalityczną), niemiecko-szwajcarską szkołę interpretacji, rozmaite teorie recepcji i odbioru oraz, przynajmniej do pewnego stopnia, dekonstrukcję. Między nimi mieściłyby się te nurty, które - jak amerykańska Nowa Krytyka czy polska szkoła strukturalistyczna - wywodziły się z tradycji badań formalnych, lecz wiele uwagi poświęcały interpretacjom poszczególnych tekstów, nie traktując ich bynajmniej wyłącznie jako egzemplifikacji koncepcji teoretycznych.

Przeciwstawianie poetyki - jako nauki o ogólnych, systemowych regułach budowy i funkcjonowania wypowiedzi literackiej - interpretacji - jako subiektywnej, podmiotowej praktyce skupionej na jednostkowym wymiarze dzieła literackiego i jednostkowości jego lektury, choć ma długą i ugruntowaną tradycję, odwołuje się jednak z reguły do sztywnego, scjentystycznego rozumienia poetyki, który w istocie, jak to ujmuje Anna Burzyńska, jest „zlepkiem najbardziej radykalnych sformułowań teoretyków strukturalizmu lat 60.”, powstałym „raczej w wyniku

${ }^{10}$ M.P. Markowski, Interpretacja i literatura, „Teksty Drugie” 2001, nr 5, s. 51. 
wybiórczej lektury niż w trakcie rzeczowej analizy rozmaitych jego wariantów"11. W praktyce literaturoznawczej odrębność metod oraz celów poetyki i interpretacji nie prowadziła na ogół do ich separacji czy wzajemnego wykluczania, ale raczej do poszukiwania sposobów przekroczenia luki między jednostkowością a ogólnością ${ }^{12}$. Dogmatyczne podtrzymywanie tej dychotomii wydaje się już dzisiaj anachronizmem, kojarzącym się, z jednej strony z postawą najbardziej ortodoksyjnych zwolenników strukturalistycznej poetyki lingwistycznej ${ }^{13}$, z drugiej zaś - ze stanowiskiem równie radykalnych i nieprzejednanych w swoich przekonaniach przedstawicieli opcji antyteoretycznych ${ }^{14}$.

Nawet Tzvetan Todorov w swojej Poetyce, uznawanej nie bez powodu za jeden z najpełniejszych wykładów sformalizowanej poetyki strukturalistycznej, daleki od jakiegokolwiek rewizjonizmu wobec jej podstawowych założeń, głosił komplementarność tych dwóch typów aktywności poznawczej, pisząc o ich „wzajemnym i ścisłym przenikaniu się” jako podstawie studiów literaturoznawczych:

Między poetyką a interpretacją występuje stosunek komplementarności i to w całym tego słowa znaczeniu. Teoretyczna refleksja nad poetyką, która rezygnuje z obserwacji dzieł istniejących, okazuje się jałowa i nieskuteczna. (...) Interpretacja jest wcześniejsza i zarazem późniejsza od poetyki, której pojęcia są urabiane zgodnie z potrzebami konkretnej analizy, ta z kolei może się rozwijać tylko przy użyciu narzędzi przygotowanych przez tę dyscyplinę. Żadne z obu poczynań nie jest pierwsze w stosunku do drugiego, oba są niejako „wtórne”. To wzajemne i ścisłe przenikanie się (...) powoduje, że studia literaturoznawcze są często nieustannym krążeniem między poetyką a interpretacją ${ }^{15}$.

Todorov podkreśla, że rozróżnienie celów i metod poetyki i interpretacji jest możliwe, a nawet ze wszech miar pożądane „w płaszczyźnie abstrakcyjnej”. Tam natomiast, gdzie w grę wchodzi literaturoznawcza praktyka lekturowa, a więc obcowanie z konkretnymi tekstami literackimi, mamy do czynienia z „nieustannym krążeniem między poetyką a interpretacją”, które należy uznać za istotę „studiów literaturoznawczych”. Janusz Sławiński skłonny był, jak wiadomo, uznawać analizę poetologiczną utworu literackiego za wstępną fazę przygotowującą jego interpretację (choć nie ukrywał, że obie procedury poznawcze rządzą się odmiennymi prawami i na inne cele są zorientowane, a więc nie może być między nimi naturalnego i łagodnego przejścia) ${ }^{16}$. W podobny sposób postrzegał związek między analizą strukturalną a interpretacją hermeneutyczną Paul Ricoeur.

${ }^{11}$ A. Burzyńska, Poetyka po strukturalizmie, [w:] tejże, Anty-teoria literatury, Kraków 2006, s. 381, przypis 9.

${ }^{12}$ Zob. R. Seamons, Poetics Against Itself. On the Self-Destruction of Modern Scientific Criticism, „PMLA” 1989, nr 3, s. 303.

${ }^{13}$ Postawie takiej jeszcze w połowie lat 80. ubiegłego wieku dawała wyraz Maria Renata Mayenowa w obszernym posłowiu do Poetyki Todorova, w którym, polemizując z francuskim badaczem, stwierdzała stanowczo, że „te dwie postawy [poetyki i interpretacji - T.K.] są całkowicie nie do pogodzenia i nie mogą tworzyć dwóch komplementarnych poznawczych aktywności”, a „koncyliacyjnej” próby ich łączenia nie uznawała za „możliwą i potrzebną". M.R. Mayenowa, O perspektywie poetyki inaczej, [w:] T. Todorov, Poetyka, przeł. S. Cichowicz, Warszawa 1984, s. 119.

${ }^{14}$ Restrykcyjność i szkodliwość wszelkiej teorii, w tym także poetyki rozumianej jako ogólna teoria budowy dzieła literackiego, sygnalizowali między innymi Steven Knapp i Walter Benn Michaels w Against Theory („Critical Inquiry" 1982, vol. 8, nr 4.

${ }^{15}$ T. Todorov, Poetyka, dz. cyt., s. 13-14 [wyróżnienie moje - T.K.].

${ }^{16}$ Krytykę wpisanego w to stanowiska dualizmu metodologicznego przeprowadził Andrzej Szahaj. Zob. A. Szahaj, Sławiński o interpretacji. Analiza krytyczna, „Teksty Drugie” 2013, nr 5, s. 259-276. 
U Todorova ta wzajemna relacja przybiera intrygującą formę, przywodzącą na myśl pozbawioną zarówno bezwzględnego początku, jak i wyraźnego następstwa oscylację, okrężny czy raczej wahadłowy ruch, który wymaga nieustannego weryfikowania efektów interpretacji w ogólnych językowych regułach konstruowania znaczeń - zarówno tych specyficznych dla literatury w jej wąskim, instytucjonalnym wymiarze (gatunkowym, stylistycznym, intertekstualnym), jak i tych dających się wyprowadzić z ogólnych semiotycznych reguł tworzenia znaczących wypowiedzi, w obrębie których język dzieła literackiego traktowany jest jako jedna z odmian kodu, podlegająca ogólnym zasadom rozumienia właściwym semiotyce jako nauce o znakach. Możliwość rozpoznania ogólnych reguł organizacji dzieła literackiego wynika zaś „z obserwacji dzieł istniejących”17. To one, stając się przedmiotem analizy literaturoznawczej, definiują aktualny stan i kondycję poetyki, która zachowuje swoją uniwersalność, lecz jednocześnie musi wciąż doskonalić i usprawniać swoje narzędzia, dostosowując je do zmieniających się potrzeb, określanych przez nowe dzieła literackie, które domagają się nowych, a przynajmniej zmodyfikowanych narzędzi opisu.

Rzecz w tym, że współczesna „praktyka literaturoznawcza”, łącząca w sobie obie te „postawy” poetyki i interpretacji - nie jest już uwarunkowana przez swój tradycyjny przedmiot, lecz okazuje się szczególną procedurą, jaką można stosować - z różnym powodzeniem - do wszelkiego typu tekstów, także tych, które nie mają właściwości przypisywanych w danym momencie historycznym tekstom literackim ${ }^{18}$. Efekty owej „literackiej” procedury analityczno-interpretacyjnej, która dociekanie znaczenia tekstu łączy z analizą jego formalnych właściwości decydujących o funkcji komunikacyjnej, mogą prowadzić - i często prowadzą - do poszerzenia repertuaru narzędzi i pojęć operacyjnych samej poetyki. W ślad za rozszerzeniem jej instrumentarium idzie zaś możliwość rozszerzenia jej kompetencji i pola przedmiotowego. Tak właśnie dokonuje się owo wzajemne przekształcenie, w którym poetyka - ograniczona dotychczas do badania „literackości” jako szczególnej funkcji języka definiującej dzieło literackie - traci swój wymiar autonomiczny, „neutralny” i nieuwarunkowany kulturowo oraz nabiera wymiaru kulturowego dzięki przenikaniu w jej obręb inspiracji płynących ze strony innych niż literackie dyskursów, które z kolei uświadamiają sobie swój tekstowy charakter za sprawą spektakularnej ekspansji kategorii i pojęć wypracowanych przez poetykę. Skoro jednak pole przedmiotowe poetyki nie jest już polem literackim, to literatura staje się w nim z konieczności zaledwie jedną z form znaczącej ekspresji, bynajmniej nieuprzywilejowaną, zmuszoną walczyć o swoją pozycję, lecz pozbawioną głównego oręża, jakim było właśnie gwarantowane przez tradycyjną, formalno-strukturalistyczną poetykę i teorię literatury przeświadczenie o jej szczególnym statusie i specyficznych cechach. Dziś, walcząc o swój prestiż, musi ona z reguły sięgać po argumenty pragmatyczne i utylitarne, dowodząc swojej użyteczności w osiąganiu różnych, bez wątpienia ważnych, lecz nieswoistych dla niej celów (egzystencjalnych, społecznych, politycznych czy emancypacyjnych) ${ }^{19}$ - przy całkowi-

\footnotetext{
${ }^{17}$ T. Todorov, Poetyka, s. 13.

${ }^{18} \mathrm{O}$ potrzebie opracowania pluralistycznych „poetyk”, rozumianych jako swoiste słowniki terminów analitycznych dostosowanych do potrzeb nowych języków krytycznych i teoretycznych zob. A.F. Kola, Języki teorii - języki poetyki. O zmianie paradygmatu, która wciąż czeka na dopetnienie, „Tekstualia” 2013, nr 4, s. 93-104.

${ }^{19}$ To samo dotyczy badań literackich, które wyzbywając się swoistego dla nich teoretycznego „oprzyrządowania”, metodologii i poetyki opisowej stworzonej na użytek analizy i interpretacji tekstów literackich, mogą służyć już tylko celom pozaestetycznym, a więc tak czy inaczej wobec niej zewnętrznym: egzystencjalnym, jak w projekcie „humanistyki wrażliwości” Michała Pawła Markowskiego, w której interpretacja literatury służy odnawianiu naszych relacji ze światem i innymi ludźmi, albo politycznym, jak w zarysowanym przez Jana Sowę w krytycznej wobec założeń Markowskiego recenzji jego książki projekcie „humanistyki emancypacyjnej”, w której interpretacja postrzegana jest przede wszystkim jako narzędzie walki o sprawiedliwość społeczną.
} 
tej niemal marginalizacji aspektu estetycznego, owej „celowości bez celu”, stanowiącej niegdyś istotę dzieła sztuki w ogóle. To zmarginalizowanie estetycznego wymiaru dzieła literackiego jest naturalną pochodną dewaluacjji klasycznej poetyki, nie sposób bowiem mówić o estetycznych czy artystycznych właściwościach i zaletach utworu literackiego, nie odwołując się do jego cech formalnych - konwencji językowych, gatunkowych czy stylistycznych - które ujmowane są w perspektywie historycznej na tle literackiej tradycji: zachodzących w niej oraz tworzących jej dzieje przemian i ewolucji. Należy pamiętać, że spektakularnej ekspansji poetyki na innych niż literaturoznawcze polach humanistycznej refleksji towarzyszy jednoczesna dewaluacja formalistyczno-strukturalnych modeli poetyki, służących uogólnionemu opisowi dzieła literackiego, oraz przekształcanie się tradycyjnego przedmiotu jej zainteresowań, a więc odejście od badania tekstów literackich i zwrot w stronę szeroko rozumianych, „dyskursywnych” praktyk kulturowych - społecznych, politycznych czy ideologicznych.

We współczesnych, kulturowo zorientowanych badaniach literackich nie mówi się już zatem o refleksji „teoretycznoliterackiej”, ale raczej o refleksji „teoretyczno-kulturowej”, w obrębie której obok siebie i na równych prawach występują kategorie zaczerpnięte z klasycznej poetyki, takie jak narracja, gatunek czy fikcja, oraz pojęcia wywodzące się z antropologii, etnografii czy badań kulturowych, takie jak etniczność, płeć kulturowa czy ciało. Nie byłoby w tym nic osobliwego, zważywszy że w XX-wiecznej teorii literatury asymilowanie kategorii, pojęć czy całych metodologii badawczych zaczerpniętych z innych dziedzin wiedzy nie było niczym wyjątkowym - dość wspomnieć inspiracje psychoanalityczne, krytykę mitograficzną, krytykę marksistowską czy socjologię literatury ${ }^{20}$. Za każdym razem jednak zapożyczenia te służyć miały lepszemu - pełniejszemu, bardziej wszechstronnemu - rozpoznaniu problematyki właściwej dla owej wyodrębnionej dziedziny badawczej, której przedmiotem były dzieła literackie. Dzisiejsza przemiana polega natomiast na zasadniczym przekształceniu nie tylko samej refleksji teoretycznoliterackiej, ale także jej przedmiotu poprzez przemieszczenie go ze względnie autonomicznej dziedziny tworów językowych, wyróżnianych na podstawie - zawsze nieostatecznych, dyskusyjnych i tymczasowych - właściwości formalnych i semantycznych, w kierunku znacznie mniej sprecyzowanego pola kultury. Na jego obszarze oprócz literatury znajdują się także wszelkie inne formy twórczej i znaczącej (sensoproduktywnej) działalności człowieka. Sięga ono także dalej ku jeszcze rozleglejszej dziedzinie ludzkiego doświadczenia jako kategorii nadrzędnej wobec wszelkich - dyskursywnych i niedyskursywnych, racjonalnych i afektywnych, świadomych i nieświadomych - form międzyludzkiej komunikacji.

Przesunięcie wytworów kultury literackiej do tak szeroko rozumianej dziedziny pozbawia ją statusu odrębnego i dającego się choćby prowizorycznie zdefiniować przedmiotu literackiego

\footnotetext{
${ }^{20} \mathrm{~W}$ istocie wszak cała nowoczesna teoria literatury w jej najbardziej wpływowej odmianie formalistycznostrukturalnej wywodzi się z refleksji językoznawczej. To od językoznawców zapożyczyła ona szereg swoich podstawowych pojęć oraz metod badania dzieła literackiego. Pierwsi nowocześni badacze literatury byli często przede wszystkim językoznawcami, można więc z niewielką tylko przesadą powiedzieć, że autonomiczne pole literackie zostało wytworzone i wyodrębnione jako efekt zapożyczenia się w lingwistyce, a więc sama autonomia nowoczesnej teorii literatury zadłużona jest nieuchronnie w dyscyplinie odrębnej od niej, której pokrewieństwo nie jest wcale oczywiste i wynika z przyjęcia szczególnej, lecz wcale niekoniecznej koncepcji dzieła literackiego jako intencjonalnego tworu językowego rządzącego się szczególnymi zasadami organizacji strukturalnosemantycznej. Przyjęcie perspektywy hermeneutycznej nie wymaga już jednak posługiwania się narzędziami językoznawczymi, a tym samym stawia pod znakiem zapytania ścisłe pokrewieństwo obu dyscyplin, które z perspektywy formalistyczno-strukturalnej wydaje się oczywiste.
} 
i przekształca go w przedmiot kulturowy. Od tego momentu wszelkie próby esencjalistycznego zdefiniowania własnego przedmiotu i własnej natury przez literaturoznawstwo okazują się daremne. Zastępują je, charakterystyczne dla badań kulturowych, definicje wąskooperacyjne - odwołujące się do aspektu pragmatycznego, ujmującego twórczość literacką i jej badanie w kategoriach praktycznych (głównie egzystencjalno-antropologicznych) jako swoistą „praktykę rozumienia”- lub też szerokozakresowe, odbierające literaturze jej specyfikę i czyniące $\mathrm{z}$ niej jedną z odmian aktywności kulturowej człowieka, bynajmniej nieuprzywilejowaną, traktowaną często instrumentalnie i upraszczająco. Uświadomienie sobie zasadniczej niemożności oddzielenia przedmiotu poznania od samego aktu poznania sprawia z kolei, że w centrum zainteresowania znajdują się już nie właściwości samego obiektu poznania (problematyka ontologiczna), nie intersubiektywne procedury służące jego poznaniu (problematyka epistemologiczna), ale nasze sposoby jego poznawania/doznawania, będące zarazem sposobami jego kształtowania/formowania i zwrotnie także kształtowania/formowania nas samych (problematyka egzystencjalna). To partycypacyjne ujęcie relacji podmiot-przedmiot, charakterystyczne dla pragmatycznej, egzystencjalnej hermeneutyki, jest zresztą znamienne także dla innych dziedzin humanistyki: w badaniach antropologiczno-kulturowych można zaobserwować przejście od „obserwacji uczestniczącej”, typowej dla tradycyjnej, „etnograficznej” antropologii, do "gęstego opisu” jako metody swoistej dla ponowoczesnej, „literackiej” antropologii, w której przedmiot opisu jest nie tyle odkrywany, ile konstruowany. W historiografii dokonało się podobne przejście od przedmiotowego rozumienia dziejów jako zbioru obiektywnych faktów domagających się rekonstrukcji i bezstronnego ukazania do koncepcji historii jako opowieści podporządkowanej tropologicznym regułom narracyjnym i będącej zawsze przede wszystkim wytworem samego opowiadającego.

W takiej sytuacji trudno już zatem mówić o „zagarnianiu” przez poetykę nowych obszarów przedmiotowych czy asymilowaniu kategorii i pojęć należących do innych dziedzin refleksji humanistycznej. Zniesieniu ulegają bowiem zarówno wyraźne granice oddzielające od siebie poszczególne dyscypliny, jak i owa bardziej podstawowa granica oddzielająca badany przedmiot od badacza, która pozwala wypracować metodologiczne podstawy badań oraz właściwe dla nich procedury regulacyjne i weryfikacyjne ${ }^{21}$. Upieranie się przy możliwości zachowania $\mathrm{w}$ tak zreorganizowanym polu jakiejś wyrazistej specyfiki przedmiotowej i metodologiczno-pojęciowej, pozwalającej podtrzymać chociażby względną specyfikę i odrębność przedmiotu badań literaturoznawczych, wydaje się nie wystarczająco uwzględniać przekształcenia wynikające z zaniku owych dyscyplinowych i epistemologicznych dystynkcji. Nawet jeśli w trybie proklamacyjnym udałoby się, za cenę sporego konceptualnego wysiłku, ocalić ową względną specyfikę, to wydaje się ona stanowczo zbyt mało znacząca, aby umożliwić w praktyce przetrwanie studiów literackich jako odrębnej dyscypliny. Ceną zaś, jaką przychodzi płacić za użytkowanie na innych polach problemowych i do innych od pierwotnie założonych celów kategorii oraz pojęć wypracowanych przez poetykę i teorię literatury do badania tekstów literackich (narracji, gatunku, fikcji), jest stopniowa utrata ich „tożsamości” czyli oryginalnego, właściwego im znaczenia i funkcji.

\footnotetext{
${ }^{21} \mathrm{Nie}$ jest zatem przypadkiem, że trudno właściwie mówić w sensie ścisłym o metodologii badań kulturowych, które cechuje raczej programowa ateoretyczność i dość swobodny synkretyzm metodologiczny (przypadki odmienne, jak choćby propozycja Mieke Bal, cechująca się znaczną systematycznością i świadomością teoretyczną, należą do rzadkości i raczej potwierdzają, niż podważają to przekonanie).
} 
Znamiennym, jak sądzę, i szczególnie pouczającym przykładem owego procesu „utraty tożsamości” jest właśnie nowe, „kulturowe”, nadzwyczaj szerokie rozumienie samej poetyki, która w praktyce oznacza dziś opis i analizę nie tylko znaczących praktyk dyskursywnych, ale dowolnej aktywności ludzkiej, w której dają się dostrzec jakieś ogólne, przynajmniej w pewnym stopniu powtarzalne reguły semiotycznego uporządkowania, uchwytne w kategoriach celowości, prawidłowości i wewnętrznej organizacji. Prowadzi to do tak głębokiego przekształcenia pierwotnej semantyki owego pojęcia, że odrywa się ono od swego macierzystego pola znaczeniowego, projektując całkowicie nowy obszar problemowy, a także nowe zasady wykorzystania samych narzędzi poetologicznych między innymi poprzez doinwestowanie ich „praktycznego", inwencyjno-sprawczego wymiaru kosztem tradycyjnej funkcji deskrypcyjno-systematyzującej. Nie jestem przeciwnikiem tego rodzaju zabiegów. Dostrzegam i doceniam płynące z nich korzyści, nie sądzę jednak, aby służyły one akurat wzmocnieniu pozycji studiów literackich, gdyż przekonanie o prototypowym charakterze zjawisk literackich, jako modelowych przykładów dla nowego zastosowania - poza sferą autonomicznie pojmowanej literackości sprawdzonych w odniesieniu do dzieł literackich pojęć i kategorii, wydaje się złudzeniem podtrzymywanym przez literaturoznawców, dla których, z racji ich profesjonalnego, wąskospecjalistycznego wykształcenia, które zdążyli jeszcze odebrać na studiach polonistycznych, właśnie literatura stanowi naturalny obszar egzemplifikacji i odniesień przedmiotowych. Dla badaczy o nieliteraturocentrycznej orientacji zjawiskami prototypowymi nie będą już jednak utwory literackie, ale na przykład kultura audiowizualna, film, praktyki codzienności, zjawiska z zakresu mikrosocjologii et cetera, co może spowodować - nietrudno wszak wyobrazić sobie taką sytuację - że w ich ujęciu „poetyka doświadczenia” czy „somatopoetyka” obywać się będą doskonale bez odniesień do literatury lub też że te ostatnie zajmować będą pozycję marginalną, jaką w literaturocentrycznych poetykach kulturowych zajmują film, teatr, sztuki plastyczne, nowe media, architektura przestrzeni czy historia obyczajów.

Jeśli zgodzimy się jednak, że dzisiaj warto jeszcze bronić specyfiki i odrębności studiów literackich (także, a może przede wszystkim tych zorientowanych kulturowo), to ich dyscyplinowa tożsamość wymaga podtrzymania nie tyle szerokiego, kulturowego rozumienia poetyki, ile właśnie wąskich, specjalistycznych umiejętności analitycznych, niezbędnych dla przetrwania tej wyjątkowej formy lektury, jaką stanowi lektura literacka, pojęta jako działalność hermeneutyczna, nakierowana na możliwie wszechstronne rozumienie tekstu, różniąca się jednak od wszelkich innych aktów hermeneutycznych właśnie wykorzystaniem specyficznych narzędzi, jakich dostarczają tradycyjne poetyki teoretyczne i opisowe, spowalniające proces interpretacji, odbierające mu doraźny, utylitarny charakter i przypominające o zaniedbywanym dziś nazbyt często wymiarze estetycznym, bez którego żadna koncepcja kultury i żadna koncepcja jej badania nie przybiorą wiarygodnego, zadowalającego kształtu. 


\section{SŁOWA KLUCZOWE:}

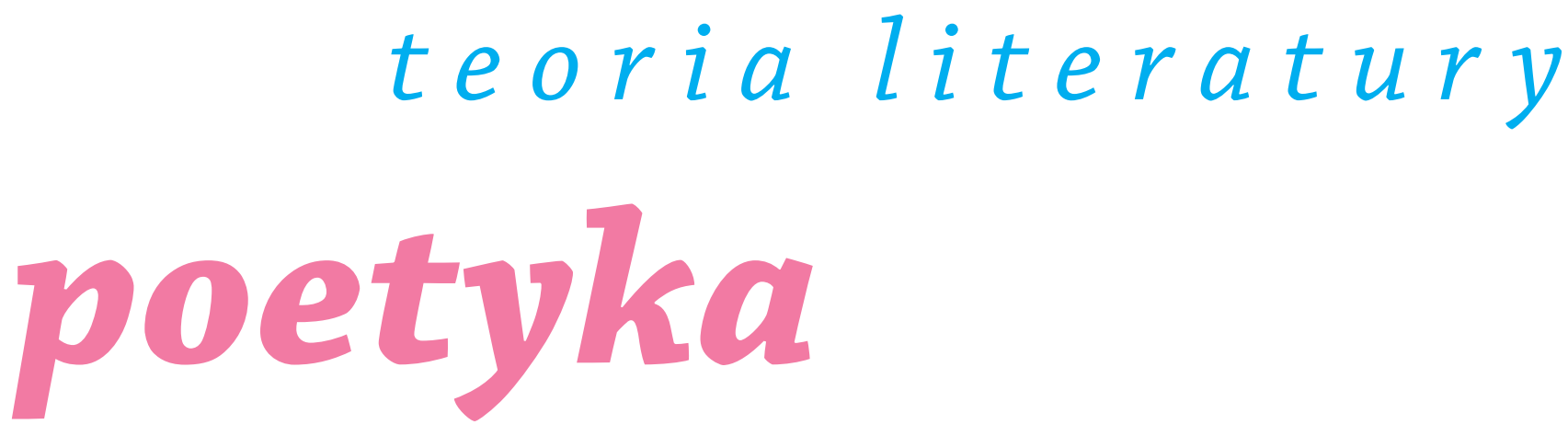

\section{A B S T R A K T :}

Artykuł pokazuje najważniejsze skutki procesu demontażu metodologicznych i epistemologicznych podstaw nowoczesnej teorii literatury, który w polskim literaturoznawstwie przybrał postać skokowej i często dość powierzchownej asymilacji radykalnych wniosków płynących z dwóch zwrotów metodologicznych - poststrukturalnego i kulturowego. Jedną z najpoważniejszych konsekwencji owego procesu było nazbyt łatwe wyrzeczenie się przez literaturoznawstwo odrębności własnego przedmiotu i własnej metodologii badawczej, będące konsekwencją kulturowej reorientacji studiów literackich. Doprowadziło to do zastąpienia teorii literatury przez ogólną teorię kultury i uczynienia z tekstu literackiego zaledwie jednego $\mathrm{z}$ wielu równoprawnych przedmiotów kulturotwórczej praktyki. Na tle nowoczesnej teorii literatury, która posiada już dzisiaj wyłącznie charakter historyczny, poetyka okazuje się dyscypliną nie tylko żywotną i ekspansywną (o czym świadczy wykorzystywanie przez inne dziedziny wiedzy wypracowanych przez nią pojęć i kategorii), ale także nieodzowną dla dalszego trwania kulturowo zorientowanych studiów literacki. Tylko ona bowiem dostarcza narzędzi pozwalających skutecznie argumentować na rzecz odrębności i specyfiki literatury jako pod wieloma względami uprzywilejowanej formy poznania i ekspresji kulturowego doświadczenia człowieka, wyróżniającej się szczególnymi właściwościami formalnymi i semantycznymi, czyniącymi z niej jedyny w swoim rodzaju kod międzyludzkiej komunikacji. 


\title{
ZWROT KULTUROWY
}

\section{poetyka kulturowa}

\author{
kulturoznawstwo
}

N O T A O A U T O R Z E :

Tomasz Kunz, dr, adiunkt w Katedrze Antropologii Literatury i Badań Kulturowych, tłumacz, historyk i teoretyk literatury. Autor książki Strategie negatywne w poezji Tadeusza Różewicza (Wyd. Universitas, Kraków 2005), za którą otrzymał Nagrodę Ministra Nauki i Szkolnictwa Wyższego. Współredaktor (wraz z Władysławem Miodunką i Ryszardem Nyczem) dwutomowej publikacji Polonistyka bez granic (Kraków 2010) oraz (wraz z Joanną Orską) tomu Próba rekonstrukcji. Szkice o twórczości Tadeusza Różewicza (Kraków 2014). Sekretarz redakcji „Wielogłosu”, pisma Wydziału Polonistyki UJ, redaktor serii naukowej „Decyzje krytyczne” (Wydawnictwo EMG). Mieszka w Krakowie. 